\title{
The Zipf's Law and Other Ways of Identifying Culture-Specific Linguistics Units
}

D.M. Akizhanova, ${ }^{+*}$ Sh.K. Zharkynbekova ${ }^{\dagger}$ and S.K. Satenova ${ }^{\dagger}$

\section{Abstract}

Every language contains a number of linguistic units that serve as a key to understanding the culture of its language speakers. Therefore, they bear specific information that helps to reveal cultural similarities and dissimilarities. Taking into account contemporary studies and focus of the science, this information can be very critical and relevant in intercultural communication. In this paper, we name such linguistic units as cultural keywords. So, we claim that cultural keywords can serve as a tool for intercultural communication. They are indicators for describing and understanding cultures. This can help to study, learn, discuss and describe the cultures of different nations all over the world. In the paper we suggest methodologies to identify cultural keywords. We claim that a methodological basis for the study may consist of three methods: semantic analysis, argumentative analysis and the Zipf's law. However, these are not comprehensive methods for discovering the keywords. Findings of the research can be applied to intercultural and cross-cultural studies as well as other interdisciplinary cultural studies.

Keywords: Culture-Specific Linguistic Units, Cultural Keyword, Argumentum Model of Topics, Argumentative Analysis, Semantic Analysis, The Zipf's Law

\footnotetext{
${ }^{\dagger}$ L.N. Gumilyov Eurasian National University 010000 Kazakhstan, Astana, 2 Satpayev str., Bldg. 5

${ }^{*}$ Corresponding Author, Email: diana.akizhanova@bk.ru

(C) 2018 Akizhanova et al. This is an Open Access article distributed under the terms of the Creative Commons Attribution License (http://creativecommons.org/licenses/by/2.0), which permits unrestricted use, distribution, and reproduction in any medium, provided the original work is properly cited.
} 


\section{Introduction}

Nowadays keywords are used in many fields of science. For example, in a corpus and computational linguistics, they are used for indexing texts in search engines, in marketing to sell the goods via the internet, etc. A keyword bears information, and this characteristic feature makes it valuable. As for intercultural communication, keywords are used to describe and explain the cultures.

The first works related to cultural keywords go back to Raymond Williams in his sociological studies. The author defined keywords as "significant, binding words in certain activities and their interpretation; they are significant, indicative words in certain forms of thought" (Williams, 1976: 13). He made an attempt to find a number of words that play particular importance. Williams noted the words society, industry, democracy, class, art and culture which reflect the changes occurred in life and society.

Another direction in the study of cultural keywords was given in the works of Polish linguist Anna Wierzbicka. She made a comparative analysis of certain languages paying more attention to the semantic meaning of words. Wierzbicka defines them as the words that have some specific meaning to the culture: "Keywords are words which are particularly important and revealing in a given culture. For example, in my Semantics, culture and cognition, I tried to show that the Russian words sud'ba (roughly 'fate'), duša (roughly 'soul'), and toska (roughly, 'melancholy-cumyearning') play a particularly important role in Russian culture and offer invaluable insight into this culture" (Wierzbicka, 1997:15). According to the author, such keywords can be referred to as "coins in a shared conceptual and communicative currency", which shape the way people think about themselves and others (Wierzbicka, 2008: 408). Other studies relate cultural keywords with discourse and think that they can influence on the logical assumptions and interpretations. Thus, Levisen and Waters consider cultural keywords as "culturally laden words around which whole discourses are organised," they govern the shared cognitive outlook of speaker and encode certain culturespecific logics, and impose on their speakers a certain interpretative grid through which they make sense of the world (Levisen \& Waters, 2017:3).

Rocci and Monteiro associate cultural keywords with evaluative connotations that are particularly revealing of a culture's beliefs or values (Rocci \& Monteiro, 2009).

According to Rigotti and Rocci, cultural keywords are the "words that are particularly revealing of a culture that can give access to the inner workings of culture as a whole, to its fundamental beliefs, values, institutions and customs. In short, [...] words that explain a culture" (Rigotti \& Rocci, 2005, pp. 125-126).

The more associations the representative of this nation has in pronouncing the word, the more important it is to the national culture. Words with the rich associative field are usually depicted in the folklore and in the works that become national classics. These words of special importance and indicative of a single culture are called keywords (Klueva, 2009).

Cultural keywords play a prominent and important role in any language. They bear cultural values and embody ways of thinking and feeling. Akizhanova et al. (2014) consider cultural keywords as significant catalysts in communicative interaction. The authors refer to Liebert's definition by identifying them "as linguistic points of reference within a communicative process" (Liebert, 1994: 453, see, also, Akizhanova et al., 2014).

Currently, cultural keywords have also been studied in argumentation. Thus, Bigi says: "keywords are lexical items that cannot be lacking if the text is to achieve the communicative goal defined by the connective predicate... Since arguments are the "bricks" for the construction of an argumentative text, keywords can be defined as the words giving arguments their persuasive power" (Bigi, 2007:130).

In corpus stylistic studies, namely, keywords analyses and studies of collocations the works 
of M. Stubbs and M. Scott (Stubbs, 2005, Scott, 1999) are significant. In this aspect, keyword refers to a "word that occurs with unusual frequency in a given text or collection of texts when this is compared with a reference corpus of some kind. Crucially, this means that a keyword can be unusually frequent or infrequent. Keyness is thus defined in terms of statistical 'unusuality'” (Bednarek, 2007: 4).

\section{Methods and Materials}

Having studied research papers related to keywords, we witness three main domains of the study - semantic analysis (A. Wierzbicka), argumentative analysis (E. Rigotti, A. Rocci, S. Greco Morasso, S. Bigi, I.A. Filimon) and cultural studies (Raymond Williams, etc.). As a methodology for the research, we apply the Zipf's law as a formula for identifying keywords in large-scale texts. Since texts reflect synchronic and diachronic states of cultures (in the meaning of a nation), we consider it helpful in identifying cultural keywords. Hence, the data obtained from the analysis of the texts using Zipf's law will contribute to the study of culture as a whole.

For this reason, we consider three methods, as already mentioned as a basis for keywords discovery. They are argumentative analysis, the Zipf's law and semantic analysis.

Argumentation contributes to the study of cultural keywords in making an argumentative analysis based on Argumentum Model of Topics (AMT) developed by F.H. van Eemeren, R. Grootendorst, E. Rigotti and other colleagues (Rigotti \& Greco, 2006, Rigotti, 2006, 2007, 2008, Rigotti \& Greco, 2009, 2010). An example of argumentative analysis of cultural keywords in a business letter was made by Akizhanova D., Kamzabekuly D., Satenova S., Kyzyrova A. (2014). Additional information on AMT can be found in the works of F.H. van Eemeren (2002); Eemeren, F. H. van \& R. Grootendorst (1984, 1992, 2004); Eemeren, F. H. van, R. Grootendorst \& A. F. Snoeck Henkenmans
(2002); Eemeren, F. H. van \& Houtlosser, P. (2002, 2006); R. Grootendorst, B. Garssen (1995, 1999, 2002), E. Rigotti, A. Rocci, \&A. F. Snoeck Henkenmans (1992), etc.

The third way to discover cultural keywords is the Zipf's law. Mostly, text analysis according to the Zipf's law is used in computational linguistics, in particular for SEO-analysis, etc. The American linguist George Kingsley Zipf (1902-1950) in 1949 actively popularised this law. However, this was first discovered by French stenographer Jean-Baptiste Estoup (1868-1950) by proposing to use this law to describe the distribution of economic power and social status (Zipf, 1949).

The Zipf's law is an empirical law of distributing frequency of words in natural language: if we put all the words of the language (or a long text) in descending order of frequency of use, the frequency of the $n$-th word in this list will be approximately inversely proportional to its ordinal number $n$, that is, the rank of this word. For example, the second word in the use is used about twice less than the first one, the third word - is met three times less than the first one, and so on.

The scientist first showed the distribution of income of people by their size: the richest man has twice as much money than the next rich man, and so on. This statement proved to be true for a number of countries (England, France, Denmark, Holland, Finland, Germany, the United States) in the period from 1926 to 1936. This law is also working on cities distribution system: the city with the largest population of any country is twice more than the next largest city, and so on (Zipf, 1949). If we list all cities of any country in the descending order of population, then each city can be attributed to a certain rank, that is, the ordinal number in this list. Herewith the population and the rank are subject to simple laws, expressed by the formula:

$$
P n=P_{1} / n
$$

Where $P_{n}$ is the population of the city of $n^{\text {th }}$ rank; 
$P_{1}$ is the population of the main city of the country (rank 1) (Zanadvorov \& Zanadvorova, 2003).

The same can be applied to the language. All the words in a language (or a text) form a hyperbola in relation to the frequency of the words. So, the Zipf's law represents the following formula (1):

$$
F \times R=C
$$

Where,

$\mathrm{F}-$ is the frequency of the word,

$\mathrm{R}$ - is rank, that is, the ordinal number of the word in the list

To lay on the Zipf's law in the study of keywords, we can use the following formula (2):

$$
\frac{f r}{n}=C
$$

Where,

$\mathrm{N}-$ is the number of words in the text.

\section{Discussion}

As an example, we analysed a text from worldknown Forbes magazine (www.forbes.com) with the help of text analysers. For certainty, we used two SEO-analysers: Advego (www.advego.ru) and Istio (www.istio.com). From the example, we can distinguish the socalled top words: see mobile, gaming, game, China, market, company, exports, space, industry, Chinese which are the most frequent words in the text. Since the overall context and the title of the text, it is about China's Mobile Games Market; we can see that these words serve as keywords of this text (see, Appendix and within it the Table 1 for detailed analysis). Hence, we can claim that the Zipf's law proves to be as one of the potential methodologies to discover keywords.

During the analysis, we take into account that any text can contain the so-called stop words that bear no significance for semantic analysis. Such stop words usually include: the, a, be, and, of, in, to, as, so, with, but, by, into, on, who, an, do, if, not, or, than, up, what, etc.

Similar to the arguments as made by Wierzbicka (1997: 16), we too argue that "there is no objective method to identify keywords in a culture". This analysis has shown that the most important criterion for keywords identification in this method is frequency.
However, we should take into account articles (definite and indefinite), prepositions, past, present and future tense forms of verbs (be, have), auxiliary verbs, etc. that cannot be considered independent words having any functionality in this analysis. Therefore, the use of this method should be adjusted from language to language, and we cannot state that this methodology is final. This is because it can be applied only in combination with other methods for keywords discovery.

Another way to identify keywords is semantic analysis. Semantic analysis helps us to search for the history, etymology of a certain word. For example, in such Kazakh collocations as "kredit qorzhyny" (loan portfolio), "tutynushy qorzhyny" (consumer goods basket), "valyuta qorzhyny" (currency basket) the main word, that is, the keyword is translated into Kazakhs as "qorzhyn". This can be explained by the history, customs and traditions of the Kazakh people.

Qorzhyn is a national domestic product woven from woollen yarn, which is used for various household items. It is made in different ways, always with elements of national patterns. The Kazakhs have used Qorzhyn since ancient times. In qorzhyn, Kazakh people kept kymyz (fermented dairy product traditionally made from mare's milk) and other beverages for a 
long time and saved its healing properties. Using qorzhyn was very practical for the Kazakh people. Besides, qorzhyn was very useful in the household; it was also used to transport products over long distances. Most often, qorzhyn was hanging on a horse or camel on the sides of the animal; the weight is evenly distributed in front of or behind the rider. It is known that double-sided qorzhyn helps animals to keep a balance, to maintain steady running and to increase endurance.

Since qorzhyn is very useful and practical in the household, this item can be observed not only in the Kazakh tradition but also in all nomadic cultures. Besides, Kazakhstan, qorzhyn was used by people of Middle Asia, Caucasus, Altai Mountains regions (Kazakh madenieti, 2005). Thus, we can meet in Turkish language Hurcin; Arabic Xurj "saddlebag"; Pers. Xurjīn; Azeri Hurcun; Armenian lunın̨hl, etc. (Dankoff, 1995). All these words have the same meaning: a saddle bag made of leather or fabric.

However, qorzhyn in the recent period has been changed and is used in the meaning close to the basket, bag, portfolio, etc. Hence, we can meet such use of qorzhyn as "tutynushy qorzhyny" which is translated as market basket, inflation basket; "valyuta qorzhyny" which is translated as currency basket; "credit qorzhyny" which is translated as loan portfolio; "investitsialyq qorzhyn" which is translated as investment portfolio; "tapsyrystar qorzhyny" which is translated as dealing portfolio, order book; "saqtandyru qorzhyny" - insurance portfolio; "aktsiyalar qorzhyny" - share portfolio, stock portfolio; etc.

Semantic analysis of cultural keywords is based on the works by Wierzbicka (1991, 1996, 1997, 1999, 2001) and others such as-Agapova (2012); Faustov (2009); Pautkina (2008); Stubbs (1986); Shmelyova (1993); Shmelev (2005); Semenuyk (2002);Trufanova (2009); Zemskaya (1996), etc.

Moreover, Rigotti and Rocci suggest a rationale for testing cultural keywords by looking at the role played by words in argumentative texts: "considerations from argumentation theory can help significantly in the complex task of hypothesising and testing candidates to the status of keywords in a given culture" (Rigotti \& Rocci 2005, p. 125). The authors have combined semantic research on cultural keywords with traditional enthymematic approach to argument analysis: "We propose to consider as serious candidates for the status of cultural keywords the words that play the role of terminus medius in an enthymematic argument, functioning at the same time as pointers to an endoxon or constellation of endoxa that are used directly or indirectly to supply an unstated major premise. More precisely, words that typically have this kind of function in public argumentation within a community are likely candidates to the status of keywords of that community." (Rigotti \& Rocci 2005, p. 131). Rigotti and Rocci demonstrate their approach in the following example:

He's a traitor. Therefore, he deserves to be put to death (Rigotti \& Rocci 2005, p. 130).

To reconstruct this enthymematic argument, an adequate unexpressed premise needs to be added, which could be "Traitors deserve to be put to death." The argumentation is thus reduced to the following syllogistic form:

Major premise: Traitors deserve to be put to death (unstated)

Minor premise: He is a traitor

Conclusion: He deserves to be put to death.

Thus, according to the authors, the word "traitor" plays an important role in both the logical and the communicative structures of the argument: "From a logical viewpoint, it appears in the subject of the major premise and the predicate of the minor premise, playing the role of terminus medius in the structure of the syllogism. From a communicative viewpoint, it plays an important role in the recovery of the unstated premise." (Rigotti \& Rocci 2005, p. 130)

According to Rigotti and Rocci, the word "traitor" is associated with certain culturally 
shared beliefs and values (or at least easily accessible beliefs and values) that confirm the plausibility of the unstated premise. This type of culturally shared beliefs can, so they argue, be identified with the Aristotelian notion of endoxon (Rigotti \& Rocci 2005, pp. 130-131).

Having analysed all the methods and approaches to the study of keywords, we see that keywords can serve as a key to culture; they may facilitate understanding of the main point of a text or a culture. Moreover, cultural keywords are not necessarily single words, they can be key-clusters (repeated strings of words) or even key-phrases, when extended units of meaning (Sinclair 1996), that is, words in combination originating a unit of meaning that can be different from the sum of the constituent lexical units (Bondi \& Scott, 2010, pp. 1-18).

\section{Conclusion}

Cultural keywords are the keys to understanding cultures, understanding cultural similarities and dissimilarities. They act as catalysers of intercultural communication. In this research, we tried to identify potential methodology of keywords identification. Though this methodology is not final and complete, we assume the above mentioned three methods can contribute to keywords studies. Based on the research via these methods we identified the following criteria for cultural keywords:

- Frequency: cultural keywords appear more often in the text and the culture as whole compared to other linguistic units.

- The commonality of usage: cultural keywords are frequently and more often used in the society (mass media, daily life, literature, etc.)

- Word sense disambiguation: cultural keywords have several meanings and are used in different fields with different meanings, that is, derivative and connotative meanings;

- The capability of keywords to create derivations and associations;

- The capability of keywords to contain summarised information;

- The capability of only significant words to serve as a keyword.

Based on this research we classify extralinguistic and intralinguistic features and criteria of cultural keywords. Intralinguistic features include linguistic specificity, frequency, semantic 'richness', ability to create semantic variations, ability to create collocations and word phrases, etc. Extralinguistic features include cultural specificity of keywords, cultural contextuality, functioning as cultural symbols, ability to reflect traditional and cultural values of nations. Though, we claim that this classification is conditional to some extent since the cultural significance of cultural keywords is based on the integral principle of extralinguistic and intralinguistic criteria and features of these linguistic units.

To sum up, cultural keywords help to specify basic, key concept of a text or a culture as a whole. Regarding culture, they identify core values and traditions of a nation. Cultural keywords are used as culture indicators; same as keywords serving as bibliographical indexes, cultural keywords help to index cultures and groups of nation representatives in intercultural communication. 


\section{Appendix}

14 April 2016 07:56 PM (Source: http://www.forbes.com)

\section{China's Mobile Games Market Is Growing Up}

Take a close look at the trends in the mobile gaming market in China, and you will see the signposts of an industry that is evolving from fledgling upstart to mature market.

The mobile games segment has been staking an increasingly significant claim on the overall digital games market in China for several years. While online PC gaming is still the undisputed giant of the industry and still dwarfs mobile gaming revenue by at least three times, analytics firm DataEye - a company that works closely with my employer, Niko Partners reports that mobile games now account for nearly $40 \%$ of the country's total digital games revenue.

DataEye puts total revenues in mobile gaming at $\$ 7.94$ billion. However, that number includes revenue from exported games. Independent research by Niko Partners puts in-country revenues at $\$ 5.5$ billion - higher than that of the U.S., but lower than the roughly $\$ 18$ billion in $\mathrm{PC}$ online revenue in China.

The key thing to keep in mind here is just how fast mobile gaming's ascent in the country has been. In 2012, mobile accounted for just 5.4\% of all gaming in China. Last year, it accounted for a whopping $36.6 \%$; this is of course if we include the export value (as DataEye does). Although the growth in mobile gaming seems certain to continue, the same blistering pace is probably not sustainable in the long run. The expansion will most likely slow over time.

Here are some of the key factors that point toward an industry rapidly growing into maturity:

\section{The Big Guys are Moving In}

One of the most significant trends in the mobile gaming space last year was the arrival of China's top PC online gaming companies on the scene. The top 7 companies, which includes NetEase, Tencent, Giant among others released over 150 mobile games between them in 2015, with Tencent and NetEase accounting for the top 10 titles just between the two of them.

This was a big move for China's top online PC gaming companies: While Tencent has previously shown interest in mobile gaming, the rest of China's gaming giants had largely steered clear of the mobile space, staying focused on the bigger portion of games revenue, PC online games. The top 7's expansion into mobile gaming serves as powerful validation that mobile gaming is a space worthy of their efforts, and it will be interesting to watch how the big players shape their mobile gaming presence moving forward.

\section{Smaller Companies Are Getting Creative}

Any time major players move to plant their flag in a new space, it serves as huge validation of the market's inherent opportunity. But it also begs the question: What does the arrival of the big players on the Chinese mobile gaming scene mean for small-to-medium companies, who are now being forced to battle for users against competitors with bigger budgets and more significant name recognition?

In the face of escalating competition and the increased cost and reduced market share, it brings with it, small- to medium-sized companies are taking advantage of their biggest asset - their agility - and using it to move in new directions and forge new paths into emerging markets. Animation and comicbased games, warfare games, indie games and female-centric games - the so-called "niche" segments - have all proven to be promising stomping grounds for small- to mid-sized companies looking to get away from the marquee competition and re-establish themselves on new turf.

And in an industry that is defined by innovation, it is always worth watching where the little guys are going, because where they are going today is usually where the more prominent players will be going next. 


\section{eSports is Big Business}

Running in tandem with the arrival of the Chinese gaming giants on the mobile scene is the rise of mobile esports. This is perhaps less surprising, given that esports was one of the significant trends in the Chinese gaming industry as a whole last year, but what is surprising is how quickly an infrastructure emerged to support mobile esports.

The attention of the gaming industry giants and the massive influx of capital in the space has kicked the development of an entire mobile eSports ecosystem into hyper-drive. Developers and publishers are working hand in hand with eSports clubs, event organisers, sponsors, ecommerce sites and live broadcast platforms to build out a fully realised eSports ecosystem, making mobile esports an area to watch moving forward.

\section{Multi-Screen ("Pan Entertainment") Gaming is Climbing}

Also driving growth in the Chinese mobile gaming industry in 2015: a surge in what DataEye calls called "pan-entertainment": cross-sector collaboration between mobile gaming and other media, including books, films, animation and comics. IP-based games accounted for $16 \%$ of the total mobile gaming market, suggesting that mobile gaming may be benefiting from converts, as fans of various media find their way into mobile gaming through their favourite properties. Also worth noting is that it seems only $4 \%$ of those games had official authorisation to use the IP in question - indicating that game creator may be playing a little fast and loose with legalities in their quest to thrill gamers with mobile games based on their favourite media.

\section{HTML5 Mobile Games Are Driving Growth}

Another trend to watch in mobile gaming in China: HTML5 games. The ease of use for coding provided by HTML5 has made it a popular playground for game developers: By the end of 2015, there were more than 3,000 HTML5 mobile games active in China. $75 \%$ of those games fall in the casual games category; however, there has also been a surge in higher monetised games, such as RPGs (state the full form).

A final trend identified by DataEye that is worth noting here is the increasing use of games developed in Android - or Alibaba 's competing operating system, AliYun - for TVbased gaming. This is a nascent space in the Chinese gaming scene, and as such is ripe for growth, which would push mobile game development even farther into the TV platform.

\section{Conclusion}

So what are the main takeaways from the Chinese mobile gaming market in 2015? Growth in the space has probably peaked, but revenue will continue to climb annually. As the market matures, only the strong will survive. The big seven gaming companies will continue to assert their dominance in the space, resulting in consolidation among the tens of thousands of Chinese mobile game developers, and increasing costs for R\&D, distribution and IP rights as demand for high-quality games continues to rise.

The good news for gamers in China is that all of these developments mean two things: more options, and the opportunity to be more discerning and demand the high-quality games that they want. It will be exciting to continue to watch these trends play out in 2016 - sure to be another interesting year in mobile gaming in China. 


\section{Table 1: The Results Of The Analysis (Word Statistics Excluding Stop Words)}

\begin{tabular}{|c|c|c|c|c|c|}
\hline$\#$ & Words & $\begin{array}{l}\text { Occurrence } \\
\text { (frequency) }\end{array}$ & Relevance* $^{*}$ & $\begin{array}{l}\% \text { in the } \\
\text { core }^{* *}\end{array}$ & $\begin{array}{l}\% \text { in the } \\
\text { text }^{* * *}\end{array}$ \\
\hline 1 & mobile & 35 & 4.09 & $6.8 \%$ & $3.1 \%$ \\
\hline 2 & gaming & 31 & 3.62 & $6 \%$ & $2.7 \%$ \\
\hline 3 & game & 29 & 3.39 & $5.6 \%$ & $2.5 \%$ \\
\hline 4 & china & 12 & 1.4 & $2.3 \%$ & $1 \%$ \\
\hline 5 & market & 10 & 1.17 & $1.9 \%$ & $0.8 \%$ \\
\hline 6 & company & 9 & 1.05 & $1.7 \%$ & $0.8 \%$ \\
\hline 7 & eSports & 8 & 0.93 & $1.5 \%$ & $0.7 \%$ \\
\hline 8 & space & 8 & 0.93 & $1.5 \%$ & $0.7 \%$ \\
\hline 9 & industry & 7 & 0.81 & $1.3 \%$ & $0.6 \%$ \\
\hline 10 & chinese & 7 & 0.81 & $1.3 \%$ & $0.6 \%$ \\
\hline 11 & revenue & 6 & 0.7 & $1.1 \%$ & $0.5 \%$ \\
\hline 12 & trend & 6 & 0.7 & $1.1 \%$ & $0.5 \%$ \\
\hline 13 & move & 6 & 0.7 & $1.1 \%$ & $0.5 \%$ \\
\hline 14 & DataEye & 5 & 0.58 & $0.9 \%$ & $0.4 \%$ \\
\hline 15 & year & 5 & 0.58 & $0.9 \%$ & $0.4 \%$ \\
\hline 16 & online & 5 & 0.58 & $0.9 \%$ & $0.4 \%$ \\
\hline 17 & watch & 5 & 0.58 & $0.9 \%$ & $0.4 \%$ \\
\hline 18 & growth & 5 & 0.58 & $0.9 \%$ & $0.4 \%$ \\
\hline 19 & Giant & 5 & 0.58 & $0.9 \%$ & $0.4 \%$ \\
\hline 20 & top & 5 & 0.58 & $0.9 \%$ & $0.4 \%$ \\
\hline 21 & player & 4 & 0.46 & $0.7 \%$ & $0.3 \%$ \\
\hline 22 & html & 4 & 0.46 & $0.7 \%$ & $0.3 \%$ \\
\hline 23 & scene & 4 & 0.46 & $0.7 \%$ & $0.3 \%$ \\
\hline 24 & account & 4 & 0.46 & $0.7 \%$ & $0.3 \%$ \\
\hline 25 & include & 4 & 0.46 & $0.7 \%$ & $0.3 \%$ \\
\hline 26 & billion & 3 & 0.35 & $0.5 \%$ & $0.2 \%$ \\
\hline 27 & Tencent & 3 & 0.35 & $0.5 \%$ & $0.2 \%$ \\
\hline 28 & media & 3 & 0.35 & $0.5 \%$ & $0.2 \%$ \\
\hline 29 & increase & 3 & 0.35 & $0.5 \%$ & $0.2 \%$ \\
\hline 30 & arrival & 3 & 0.35 & $0.5 \%$ & $0.2 \%$ \\
\hline 31 & development & 3 & 0.35 & $0.5 \%$ & $0.2 \%$ \\
\hline 32 & worth & 3 & 0.35 & $0.5 \%$ & $0.2 \%$ \\
\hline 33 & developer & 3 & 0.35 & $0.5 \%$ & $0.2 \%$ \\
\hline 34 & guy & 2 & 0.23 & $0.3 \%$ & $0.1 \%$ \\
\hline 35 & cost & 2 & 0.23 & $0.3 \%$ & $0.1 \%$ \\
\hline 36 & digital & 2 & 0.23 & $0.3 \%$ & $0.1 \%$ \\
\hline 37 & NetEase & 2 & 0.23 & $0.3 \%$ & $0.1 \%$ \\
\hline 38 & significant & 2 & 0.23 & $0.3 \%$ & $0.1 \%$ \\
\hline 39 & still & 2 & 0.23 & $0.3 \%$ & $0.1 \%$ \\
\hline 40 & growing & 2 & 0.23 & $0.3 \%$ & $0.1 \%$ \\
\hline 41 & driving & 2 & 0.23 & $0.3 \%$ & $0.1 \%$ \\
\hline 42 & small- & 2 & 0.23 & $0.3 \%$ & $0.1 \%$ \\
\hline 43 & surge & 2 & 0.23 & $0.3 \%$ & $0.1 \%$ \\
\hline 44 & country & 2 & 0.23 & $0.3 \%$ & $0.1 \%$ \\
\hline
\end{tabular}




\begin{tabular}{|c|c|c|c|c|c|}
\hline 45 & interesting & 2 & 0.23 & $0.3 \%$ & $0.1 \%$ \\
\hline 46 & validation & 2 & 0.23 & $0.3 \%$ & $0.1 \%$ \\
\hline 47 & rise & 2 & 0.23 & $0.3 \%$ & $0.1 \%$ \\
\hline 48 & gamers & 2 & 0.23 & $0.3 \%$ & $0.1 \%$ \\
\hline 49 & mature & 2 & 0.23 & $0.3 \%$ & $0.1 \%$ \\
\hline 50 & segment & 2 & 0.23 & $0.3 \%$ & $0.1 \%$ \\
\hline 51 & competition & 2 & 0.23 & $0.3 \%$ & $0.1 \%$ \\
\hline 52 & high-quality & 2 & 0.23 & $0.3 \%$ & $0.1 \%$ \\
\hline 53 & another & 2 & 0.23 & $0.3 \%$ & $0.1 \%$ \\
\hline 54 & note & 2 & 0.23 & $0.3 \%$ & $0.1 \%$ \\
\hline 55 & call & 2 & 0.23 & $0.3 \%$ & $0.1 \%$ \\
\hline 56 & platform & 2 & 0.23 & $0.3 \%$ & $0.1 \%$ \\
\hline 57 & ecosystem & 2 & 0.23 & $0.3 \%$ & $0.1 \%$ \\
\hline 58 & animation & 2 & 0.23 & $0.3 \%$ & $0.1 \%$ \\
\hline 59 & Niko & 2 & 0.23 & $0.3 \%$ & $0.1 \%$ \\
\hline 60 & key & 2 & 0.23 & $0.3 \%$ & $0.1 \%$ \\
\hline 61 & partner & 2 & 0.23 & $0.3 \%$ & $0.1 \%$ \\
\hline 62 & expansion & 2 & 0.23 & $0.3 \%$ & $0.1 \%$ \\
\hline 63 & export & 2 & 0.23 & $0.3 \%$ & $0.1 \%$ \\
\hline 64 & hand & 2 & 0.23 & $0.3 \%$ & $0.1 \%$ \\
\hline 65 & revenues & 2 & 0.23 & $0.3 \%$ & $0.1 \%$ \\
\hline 66 & seem & 2 & 0.23 & $0.3 \%$ & $0.1 \%$ \\
\hline 67 & quickly & 1 & 0.11 & $0.1 \%$ & $0 \%$ \\
\hline 68 & IP-based & 1 & 0.11 & $0.1 \%$ & $0 \%$ \\
\hline 69 & clearly & 1 & 0.11 & $0.1 \%$ & $0 \%$ \\
\hline 70 & e-commerce & 1 & 0.11 & $0.1 \%$ & $0 \%$ \\
\hline 71 & working & 1 & 0.11 & $0.1 \%$ & $0 \%$ \\
\hline 72 & comic & 1 & 0.11 & $0.1 \%$ & $0 \%$ \\
\hline 73 & event & 1 & 0.11 & $0.1 \%$ & $0 \%$ \\
\hline 74 & club & 1 & 0.11 & $0.1 \%$ & $0 \%$ \\
\hline 75 & fan & 1 & 0.11 & $0.1 \%$ & $0 \%$ \\
\hline 76 & convert & 1 & 0.11 & $0.1 \%$ & $0 \%$ \\
\hline 77 & benefit & 1 & 0.11 & $0.1 \%$ & $0 \%$ \\
\hline 78 & issurprising & 1 & 0.11 & $0.1 \%$ & $0 \%$ \\
\hline 79 & publisher & 1 & 0.11 & $0.1 \%$ & $0 \%$ \\
\hline 80 & organizer & 1 & 0.11 & $0.1 \%$ & $0 \%$ \\
\hline 81 & sponsor & 1 & 0.11 & $0.1 \%$ & $0 \%$ \\
\hline 82 & collaboration & 1 & 0.11 & $0.1 \%$ & $0 \%$ \\
\hline 83 & pan-entertainment & 1 & 0.11 & $0.1 \%$ & $0 \%$ \\
\hline 84 & kick & 1 & 0.11 & $0.1 \%$ & $0 \%$ \\
\hline 85 & fully & 1 & 0.11 & $0.1 \%$ & $0 \%$ \\
\hline 86 & capital & 1 & 0.11 & $0.1 \%$ & $0 \%$ \\
\hline 87 & making & 1 & 0.11 & $0.1 \%$ & $0 \%$ \\
\hline 88 & area & 1 & 0.11 & $0.1 \%$ & $0 \%$ \\
\hline 89 & climbing & 1 & 0.11 & $0.1 \%$ & $0 \%$ \\
\hline 90 & multi-screen & 1 & 0.11 & $0.1 \%$ & $0 \%$ \\
\hline 91 & influx & 1 & 0.11 & $0.1 \%$ & $0 \%$ \\
\hline 92 & massive & 1 & 0.11 & $0.1 \%$ & $0 \%$ \\
\hline
\end{tabular}




\begin{tabular}{|c|c|c|c|c|c|}
\hline 93 & broadcast & 1 & 0.11 & $0.1 \%$ & $0 \%$ \\
\hline 94 & emerge & 1 & 0.11 & $0.1 \%$ & $0 \%$ \\
\hline 95 & book & 1 & 0.11 & $0.1 \%$ & $0 \%$ \\
\hline 96 & film & 1 & 0.11 & $0.1 \%$ & $0 \%$ \\
\hline 97 & cross-sector & 1 & 0.11 & $0.1 \%$ & $0 \%$ \\
\hline 98 & support & 1 & 0.11 & $0.1 \%$ & $0 \%$ \\
\hline 99 & build & 1 & 0.11 & $0.1 \%$ & $0 \%$ \\
\hline 100 & entire & 1 & 0.11 & $0.1 \%$ & $0 \%$ \\
\hline 101 & attention & 1 & 0.11 & $0.1 \%$ & $0 \%$ \\
\hline 102 & hyper-drive & 1 & 0.11 & $0.1 \%$ & $0 \%$ \\
\hline 103 & infrastructure & 1 & 0.11 & $0.1 \%$ & $0 \%$ \\
\hline 104 & end & 1 & 0.11 & $0.1 \%$ & $0 \%$ \\
\hline 105 & main & 1 & 0.11 & $0.1 \%$ & $0 \%$ \\
\hline 106 & conclusion & 1 & 0.11 & $0.1 \%$ & $0 \%$ \\
\hline 107 & takeaways & 1 & 0.11 & $0.1 \%$ & $0 \%$ \\
\hline 108 & peaked & 1 & 0.11 & $0.1 \%$ & $0 \%$ \\
\hline 109 & strong & 1 & 0.11 & $0.1 \%$ & $0 \%$ \\
\hline 110 & annually & 1 & 0.11 & $0.1 \%$ & $0 \%$ \\
\hline 111 & climb & 1 & 0.11 & $0.1 \%$ & $0 \%$ \\
\hline 112 & TV-based & 1 & 0.11 & $0.1 \%$ & $0 \%$ \\
\hline 113 & AliYun & 1 & 0.11 & $0.1 \%$ & $0 \%$ \\
\hline 114 & system & 1 & 0.11 & $0.1 \%$ & $0 \%$ \\
\hline 115 & nascent & 1 & 0.11 & $0.1 \%$ & $0 \%$ \\
\hline 116 & ripe & 1 & 0.11 & $0.1 \%$ & $0 \%$ \\
\hline 117 & push & 1 & 0.11 & $0.1 \%$ & $0 \%$ \\
\hline 118 & survive & 1 & 0.11 & $0.1 \%$ & $0 \%$ \\
\hline 119 & assert & 1 & 0.11 & $0.1 \%$ & $0 \%$ \\
\hline 120 & discerning & 1 & 0.11 & $0.1 \%$ & $0 \%$ \\
\hline 121 & option & 1 & 0.11 & $0.1 \%$ & $0 \%$ \\
\hline 122 & excite & 1 & 0.11 & $0.1 \%$ & $0 \%$ \\
\hline 123 & play & 1 & 0.11 & $0.1 \%$ & $0 \%$ \\
\hline 124 & distribution & 1 & 0.11 & $0.1 \%$ & $0 \%$ \\
\hline 125 & consolidation & 1 & 0.11 & $0.1 \%$ & $0 \%$ \\
\hline 126 & dominance & 1 & 0.11 & $0.1 \%$ & $0 \%$ \\
\hline 127 & ten & 1 & 0.11 & $0.1 \%$ & $0 \%$ \\
\hline 128 & thousand & 1 & 0.11 & $0.1 \%$ & $0 \%$ \\
\hline 129 & operate & 1 & 0.11 & $0.1 \%$ & $0 \%$ \\
\hline 130 & compete & 1 & 0.11 & $0.1 \%$ & $0 \%$ \\
\hline 131 & quest & 1 & 0.11 & $0.1 \%$ & $0 \%$ \\
\hline 132 & legalities & 1 & 0.11 & $0.1 \%$ & $0 \%$ \\
\hline 133 & loose & 1 & 0.11 & $0.1 \%$ & $0 \%$ \\
\hline 134 & thrill & 1 & 0.11 & $0.1 \%$ & $0 \%$ \\
\hline 135 & base & 1 & 0.11 & $0.1 \%$ & $0 \%$ \\
\hline 136 & coding & 1 & 0.11 & $0.1 \%$ & $0 \%$ \\
\hline 137 & ease & 1 & 0.11 & $0.1 \%$ & $0 \%$ \\
\hline 138 & playing & 1 & 0.11 & $0.1 \%$ & $0 \%$ \\
\hline 139 & creator & 1 & 0.11 & $0.1 \%$ & $0 \%$ \\
\hline 140 & property & 1 & 0.11 & $0.1 \%$ & $0 \%$ \\
\hline
\end{tabular}




\begin{tabular}{|c|c|c|c|c|c|}
\hline 141 & official & 1 & 0.11 & $0.1 \%$ & $0 \%$ \\
\hline 142 & indicate & 1 & 0.11 & $0.1 \%$ & $0 \%$ \\
\hline 143 & authorization & 1 & 0.11 & $0.1 \%$ & $0 \%$ \\
\hline 144 & identify & 1 & 0.11 & $0.1 \%$ & $0 \%$ \\
\hline 145 & final & 1 & 0.11 & $0.1 \%$ & $0 \%$ \\
\hline 146 & RPGs & 1 & 0.11 & $0.1 \%$ & $0 \%$ \\
\hline 147 & developed & 1 & 0.11 & $0.1 \%$ & $0 \%$ \\
\hline 148 & android & 1 & 0.11 & $0.1 \%$ & $0 \%$ \\
\hline 149 & Alibaba & 1 & 0.11 & $0.1 \%$ & $0 \%$ \\
\hline 150 & monetise & 1 & 0.11 & $0.1 \%$ & $0 \%$ \\
\hline 151 & category & 1 & 0.11 & $0.1 \%$ & $0 \%$ \\
\hline 152 & playground & 1 & 0.11 & $0.1 \%$ & $0 \%$ \\
\hline 153 & popular & 1 & 0.11 & $0.1 \%$ & $0 \%$ \\
\hline 154 & active & 1 & 0.11 & $0.1 \%$ & $0 \%$ \\
\hline 155 & casual & 1 & 0.11 & $0.1 \%$ & $0 \%$ \\
\hline 156 & fall & 1 & 0.11 & $0.1 \%$ & $0 \%$ \\
\hline 157 & various & 1 & 0.11 & $0.1 \%$ & $0 \%$ \\
\hline 158 & competitor & 1 & 0.11 & $0.1 \%$ & $0 \%$ \\
\hline 159 & sustainable & 1 & 0.11 & $0.1 \%$ & $0 \%$ \\
\hline 160 & pace & 1 & 0.11 & $0.1 \%$ & $0 \%$ \\
\hline 161 & run & 1 & 0.11 & $0.1 \%$ & $0 \%$ \\
\hline 162 & slow & 1 & 0.11 & $0.1 \%$ & $0 \%$ \\
\hline 163 & blistering & 1 & 0.11 & $0.1 \%$ & $0 \%$ \\
\hline 164 & same & 1 & 0.11 & $0.1 \%$ & $0 \%$ \\
\hline 165 & whop & 1 & 0.11 & $0.1 \%$ & $0 \%$ \\
\hline 166 & ascent & 1 & 0.11 & $0.1 \%$ & $0 \%$ \\
\hline 167 & mind & 1 & 0.11 & $0.1 \%$ & $0 \%$ \\
\hline 168 & value & 1 & 0.11 & $0.1 \%$ & $0 \%$ \\
\hline 169 & although & 1 & 0.11 & $0.1 \%$ & $0 \%$ \\
\hline 170 & factor & 1 & 0.11 & $0.1 \%$ & $0 \%$ \\
\hline 171 & rest & 1 & 0.11 & $0.1 \%$ & $0 \%$ \\
\hline 172 & interest & 1 & 0.11 & $0.1 \%$ & $0 \%$ \\
\hline 173 & largely & 1 & 0.11 & $0.1 \%$ & $0 \%$ \\
\hline 174 & steer & 1 & 0.11 & $0.1 \%$ & $0 \%$ \\
\hline 175 & stay & 1 & 0.11 & $0.1 \%$ & $0 \%$ \\
\hline 176 & clear & 1 & 0.11 & $0.1 \%$ & $0 \%$ \\
\hline 177 & title & 1 & 0.11 & $0.1 \%$ & $0 \%$ \\
\hline 178 & toward & 1 & 0.11 & $0.1 \%$ & $0 \%$ \\
\hline 179 & point & 1 & 0.11 & $0.1 \%$ & $0 \%$ \\
\hline 180 & rapidly & 1 & 0.11 & $0.1 \%$ & $0 \%$ \\
\hline 181 & maturity & 1 & 0.11 & $0.1 \%$ & $0 \%$ \\
\hline 182 & accounting & 1 & 0.11 & $0.1 \%$ & $0 \%$ \\
\hline 183 & release & 1 & 0.11 & $0.1 \%$ & $0 \%$ \\
\hline 184 & keep & 1 & 0.11 & $0.1 \%$ & $0 \%$ \\
\hline 185 & roughly & 1 & 0.11 & $0.1 \%$ & $0 \%$ \\
\hline 186 & increasingly & 1 & 0.11 & $0.1 \%$ & $0 \%$ \\
\hline 187 & stake & 1 & 0.11 & $0.1 \%$ & $0 \%$ \\
\hline 188 & upstart & 1 & 0.11 & $0.1 \%$ & $0 \%$ \\
\hline
\end{tabular}




\begin{tabular}{|c|c|c|c|c|c|}
\hline 189 & overall & 1 & 0.11 & $0.1 \%$ & $0 \%$ \\
\hline 190 & undisputed & 1 & 0.11 & $0.1 \%$ & $0 \%$ \\
\hline 191 & several & 1 & 0.11 & $0.1 \%$ & $0 \%$ \\
\hline 192 & fledgling & 1 & 0.11 & $0.1 \%$ & $0 \%$ \\
\hline 193 & evolve & 1 & 0.11 & $0.1 \%$ & $0 \%$ \\
\hline 194 & signpost & 1 & 0.11 & $0.1 \%$ & $0 \%$ \\
\hline 195 & dwarf & 1 & 0.11 & $0.1 \%$ & $0 \%$ \\
\hline 196 & least & 1 & 0.11 & $0.1 \%$ & $0 \%$ \\
\hline 197 & independent & 1 & 0.11 & $0.1 \%$ & $0 \%$ \\
\hline 198 & numb & 1 & 0.11 & $0.1 \%$ & $0 \%$ \\
\hline 199 & nearly & 1 & 0.11 & $0.1 \%$ & $0 \%$ \\
\hline 200 & research & 1 & 0.11 & $0.1 \%$ & $0 \%$ \\
\hline 201 & in-country & 1 & 0.11 & $0.1 \%$ & $0 \%$ \\
\hline 202 & report & 1 & 0.11 & $0.1 \%$ & $0 \%$ \\
\hline 203 & employer & 1 & 0.11 & $0.1 \%$ & $0 \%$ \\
\hline 204 & analytics & 1 & 0.11 & $0.1 \%$ & $0 \%$ \\
\hline 205 & firm & 1 & 0.11 & $0.1 \%$ & $0 \%$ \\
\hline 206 & closely & 1 & 0.11 & $0.1 \%$ & $0 \%$ \\
\hline 207 & focus & 1 & 0.11 & $0.1 \%$ & $0 \%$ \\
\hline 208 & portion & 1 & 0.11 & $0.1 \%$ & $0 \%$ \\
\hline 209 & stomp & 1 & 0.11 & $0.1 \%$ & $0 \%$ \\
\hline 210 & promise & 1 & 0.11 & $0.1 \%$ & $0 \%$ \\
\hline 211 & proven & 1 & 0.11 & $0.1 \%$ & $0 \%$ \\
\hline 212 & ground & 1 & 0.11 & $0.1 \%$ & $0 \%$ \\
\hline 213 & mid-sized & 1 & 0.11 & $0.1 \%$ & $0 \%$ \\
\hline 214 & niche & 1 & 0.11 & $0.1 \%$ & $0 \%$ \\
\hline 215 & so-called & 1 & 0.11 & $0.1 \%$ & $0 \%$ \\
\hline 216 & emerging & 1 & 0.11 & $0.1 \%$ & $0 \%$ \\
\hline 217 & path & 1 & 0.11 & $0.1 \%$ & $0 \%$ \\
\hline 218 & forge & 1 & 0.11 & $0.1 \%$ & $0 \%$ \\
\hline 219 & comic-based & 1 & 0.11 & $0.1 \%$ & $0 \%$ \\
\hline 220 & warfare & 1 & 0.11 & $0.1 \%$ & $0 \%$ \\
\hline 221 & female-centric & 1 & 0.11 & $0.1 \%$ & $0 \%$ \\
\hline 222 & indie & 1 & 0.11 & $0.1 \%$ & $0 \%$ \\
\hline 223 & marquee & 1 & 0.11 & $0.1 \%$ & $0 \%$ \\
\hline 224 & re-establish & 1 & 0.11 & $0.1 \%$ & $0 \%$ \\
\hline 225 & business & 1 & 0.11 & $0.1 \%$ & $0 \%$ \\
\hline 226 & next & 1 & 0.11 & $0.1 \%$ & $0 \%$ \\
\hline 227 & usually & 1 & 0.11 & $0.1 \%$ & $0 \%$ \\
\hline 228 & running & 1 & 0.11 & $0.1 \%$ & $0 \%$ \\
\hline 229 & tandem & 1 & 0.11 & $0.1 \%$ & $0 \%$ \\
\hline 230 & turf & 1 & 0.11 & $0.1 \%$ & $0 \%$ \\
\hline 231 & define & 1 & 0.11 & $0.1 \%$ & $0 \%$ \\
\hline 232 & innovation & 1 & 0.11 & $0.1 \%$ & $0 \%$ \\
\hline 233 & always & 1 & 0.11 & $0.1 \%$ & $0 \%$ \\
\hline 234 & direction & 1 & 0.11 & $0.1 \%$ & $0 \%$ \\
\hline 235 & agility & 1 & 0.11 & $0.1 \%$ & $0 \%$ \\
\hline 236 & huge & 1 & 0.11 & $0.1 \%$ & $0 \%$ \\
\hline
\end{tabular}




\begin{tabular}{llllll}
\hline 237 & flag & 1 & 0.11 & $0.1 \%$ & $0 \%$ \\
\hline 238 & plant & 1 & 0.11 & $0.1 \%$ & $0 \%$ \\
\hline 239 & beg & 1 & 0.11 & $0.1 \%$ & $0 \%$ \\
\hline 240 & small-to-medium & 1 & 0.11 & $0.1 \%$ & $0 \%$ \\
\hline 241 & creative & 1 & 0.11 & $0.1 \%$ & $0 \%$ \\
\hline 242 & worthy & 1 & 0.11 & $0.1 \%$ & $0 \%$ \\
\hline 243 & powerful & 1 & 0.11 & $0.1 \%$ & $0 \%$ \\
\hline 244 & effort & 1 & 0.11 & $0.1 \%$ & $0 \%$ \\
\hline 245 & shape & 1 & 0.11 & $0.1 \%$ & $0 \%$ \\
\hline 246 & presence & 1 & 0.11 & $0.1 \%$ & $0 \%$ \\
\hline 248 & force & 1 & 0.11 & $0.1 \%$ & $0 \%$ \\
\hline 249 & shing & 1 & 0.11 & $0.1 \%$ & $0 \%$ \\
\hline 250 & reduce & 1 & 0.11 & $0.1 \%$ & $0 \%$ \\
\hline 251 & medium-sized & 1 & 0.11 & $0.1 \%$ & $0 \%$ \\
\hline 252 & taking & 1 & 0.11 & $0.1 \%$ & $0 \%$ \\
\hline 253 & asset & 1 & 0.11 & $0.1 \%$ & $0 \%$ \\
\hline 254 & escalate & 1 & 0.11 & $0.1 \%$ & $0 \%$ \\
\hline 255 & face & 1 & 0.11 & $0.1 \%$ & $0 \%$ \\
\hline 256 & battle & 1 & 0.11 & $0.1 \%$ & $0 \%$ \\
\hline 257 & budget & 1 & 0.11 & $0.1 \%$ & $0 \%$ \\
\hline 258 & recognition & 1 & 0.11 & $0.1 \%$ & $0 \%$ \\
\hline 259 & surprise & 1 & 0.11 & $0.1 \%$ & $0 \%$ \\
\hline
\end{tabular}

* Relevance of the word describes the extent to which the word reflects the content of the text ** The percentage of the word among all significant words

*** The percentage of the word among all words including the insignificant word

\section{References}

Agapova, N. A. (2012). Klyuchevoe slovo narodnoj primety: status, svoistva, spesifika (Lingvokul'turologicheskij aspekt). Vestnik Tomskogo Gosudarstvennogo Universiteta, 365, 7-10.

Akizhanova, D., Kamzabekuly, D., Satenova, S., \& Kyzyrova, A. (2014). Argumentative analysis of cultural keywords: an exercise. Life Science Journal, 11(5), 452-458.

Bednarek, M. (2007). Teaching English literature and linguistics using corpus stylistic methods. In Bridging Discourses: ASFLA 2007 Online Proceedings (pp. 1-13).

Bigi, S. (2007). Keywords in argumentative texts and their persuasive power. In Proceedings of the Sixth Conference of the International Society for the Study of Argumentation (pp. 129-135).
Bondi, M., \& Scott, M. (Eds.). (2010). Keyness in Texts. Amsterdam, Netherlands, Philadelphia, PA: John Benjamins.

Dankoff, R. (1995). Armenian Loanwords in Turkish. Wiesbaden, Germany: Harrassowitz Verlag.

Eemeren, F. H. van (Ed.). (2002). Advances in Pragma-Dialectics. Amsterdam,

Netherlands: SicSat, Newport News.

Eemeren, F. H. van, \& Grootendorst, R. (1984). Speech Acts in Argumentative Discussions: A Theoretical Model for the Analysis of Discussions Directed Towards Solving Conflicts of Opinion. Dordrecht, Netherlands: Floris Publications.

Eemeren, F. H. van, \& Grootendorst, R. (1992). Argumentation, Communication, and Fallacies: A Pragma-Dialectical Perspective. Hillsdale, NJ: Lawrence Erlbaum Associates. 
Eemeren, F. H. van, \& Grootendorst, R. (2004). A Systematic Theory of Argumentation: The Pragma-Dialectical Approach. Cambridge, UK: Cambridge University Press.

Eemeren, F. H. van, Grootendorst, R., \& Snoeck Henkemans, A. F. (2002). Argumentation: Analysis, Evaluation, Presentation. Mahwah, NJ: Lawrence Erlbaum Associates.

Eemeren, F. H. van, \& Houtlosser, P. (2002). Strategic maneuvring with the burden of proof. In Advances in Pragma-Dialectics. Amsterdam, Netherlands: SicSat, Newport News.

Eemeren, F. H. van, \& Houtlosser, P. (2006). Strategic maneuvering: A synthetic recapitulation. Argumentation, 20, 381-392.

Faustov, A. A. (2009). Ot kljuchevykh slov k literaturnym universalijam: neskol'ko metodologicheskikh soobrazhenij. Vestnik VGU. Linguistics and Intercultural Communication, 2, 9-11.

Forbes.Retrievedfrom, https://www.forbes.com/sites/lisachanson/ 2016/04/14/chinas-mobile-games-marketis-growing-up/\#737973ce68d3

Kazakh Madenieti. Ensiklopediyalyq anyqtamalyq [Kazakh culture. Encyclopedic guide]. (2005). Almaty, Kazakhstan: Aruna Ltd.

Klueva, G. Yu. (2009). Culture keywords at Russian lessons. Yaroslavskij Pedagogicheskij Vestnik, 3(60), 24-28.

Levisen, C., \& Waters, S. (Eds.). (2017). Cultural Keywords in Discourse. Amsterdam, Netherlands, Philadelphia, PA: John Benjamins.

Liebert, W. A. (1994) Lascaux - A hypermedia lexicon of metaphor models for scientific imagination. In: Willy Martin, Willem Meijs Margreet Moerland, Elsemiek ten Pas, Piet van Sterkenburg und Piek Vossen (Hrsg.): Proceedings of the 6th EURALEX International Congress, 1994 Amsterdam, the Netherlands. Amsterdam: Euralex, 494500 .
Pautkina, A. A. (2008). Kljuchevye Slova Organizacionnoj Kul'tury Amerikanskikh Kommercheskih Kompanij Kak Otrazhenie Nacional'noj Kul'tury. Moscow, Russia: Moskovskij pedagogicheskij gosudarstvennyj universitet.

Rigotti, E. (2008). Locus ad causa finali. In Word Meaning in Argumentative Dialogue: Proceedings of the IADA workshop (Vol. 2, pp. 559-576).

Rigotti, E., \& Rocci, A. (2005). From argument analysis to cultural keywords (and back again). In F. H. van Eemeren, \& P. Houtlosser (Eds.), Argumentation In Practice (pp. 125142), Amsterdam, Netherlands, Philadelphia, PA: John Benjamins.

Rigotti, E., \& Greco, S. (2006). Topics: The Argument Generator. Retrieved from www.argumentum.ch

Rigotti, E., \& Greco, S. (2009). Argumentation as an object of interest and as a social and cultural resource. In Argumentation and Education. Theoretical Foundations and Practices (pp. 9-66). New York, NY: Springer.

Rigotti, E., \& Greco, S. (2010). Comparing the argumentum model of topics to other contemporary approaches to argument schemes: the procedural and material components. Argumentation, 24(4), 489512.

Rocci A., \& Monteiro, M. W. (2009). Cultural keywords in arguments. The case of interactivity. Cogency, 1(2), 65-100.

Scott, M. (1999). Wordsmith Tools. Oxford, UK: Oxford University Press.

Semenuyk, O. A. (2002). Kljuchevye slova v kartine mira i jazyke epokhi. Kultura narodov. Prichernomoria, 32, 129-132.

Shmelev, A. D. (2005a). Kommentarii k statje Anny Vezhbitskoi. In Klyuchevie idei russkoi yazykovoi kartiny mira. Cbornik Statei. Moscow, Russia: Yazyki slavyanskoi kul'tury.

Shmelev, A. D. (2005b). Leksicheskij sostav russkogo jazyka kak otrazhenie "russkoj dushi". In Klyuchevie idei russkoi yazykovoi 
kartiny mira. Cbornik Statei (pp. 25-36). Moscow, Russia: Yazyki slavyanskoi kul'tury.

Shmelev, A. D. (2005c). Mozhno li ponyat' russkuyu kul'turu zherez klyuchevye clova russkogo yazika? In Klyuchevie idei russkoi yazykovoi kartiny mira. Cbornik Statei. Moscow, Russia: Yazyki slavyanskoi kul'tury.

Shmelyova, T. V. (1993). Kljuchevye slova tekushhego momenta. Solleqium, 1, 33-41.

Sinclair, J. (1966). Beginning the study of lexis. C.E. Bazell, J.C. Catford, M.A.K. Halliday \& R.H. Robins (eds). In Memory of J.R. Firth. London: Longman, 410-30.

Snoeck Henkemans, A. F. (1992). Analysing Complex Argumentation: The Reconstruction of Multiple and Coordinatively Compound Argumentation in a Critical Discussion. Amsterdam, Netherlands: SicSat.

Stubbs, M. (1986). Language Development, Lexical Competence and Nuclear Vocabulary. In Educational Linguistics (pp. 98-115), Oxford, UK: Basil Blackwell.

Stubbs, M. (2005). Conrad in the computer: examples of quantitative stylistic methods. Language and Literature, 14(1), 5-24.

Trufanova, N. V. (2009). Osobennosti funkcionirovanija kljuchevykh slov sovetskogo perioda $\mathrm{v}$ sovremennoj khudozhestvennoj literature (na primere proizvedenij V. Pelevina). Russkaja filologija. Ukrainskij vestnik: Respublikanskij nauchnometodicheskij zhurnal, 38(1), 24-27.
Wierzbicka, A. (1991). Japanese key words and core cultural values. Language in Society, 20(3), 333-385.

Wierzbicka, A. (1996). Semantics: Primes and Universals. Oxford, UK: Oxford University Press.

Wierzbicka, A. (1997). Understanding Cultures Through Their Key Words: English, Russian, Polish, German, Japanese. New York, NY: Oxford University Press.

Wierzbicka, A. (1999). Emotions Across Languages and Cultures: Diversity and Universals. Cambridge, UK: Cambridge University Press.

Wierzbicka, A. (2008). Why There Are No 'Colour Universals' in Language and Thought. The Journal of the Royal Anthropological Institute, 14(2), 407-425. Retrieved from http://www.jstor.org/stable/20203637

Williams, R. (1976). Keywords - A Vocabulary of Culture and Society. London, UK: Fontana.

Zanadvorov, V. S., \& Zanadvorov, A. V. (2003). Ekonomika Goroda: Vvodnyi kurs. Moscow, Russia: Akademkniga.

Zemskaya, E. A. (1996). Aktivnye Processi Sovremennogo Slovoproizvodstva: Russkii Yazik Kontsa XX Stoletia (1985-1995). Moscow, Russia: Yazyki russkoi kul'tury.

Zipf, G. K. (1949). Human Behavior and the Principle of Least Effort. Cambridge, MA: Addison-Wesley Press. 